\title{
In vitro culture of hFOB1.19 osteoblast cells on TGF-ß1-SF-CS three-dimensional scaffolds
}

\author{
SHUANG TONG, LEI XUE, DA-PENG XU, ZI-MEI LIU, YANG DU and XU-KAI WANG \\ Department of Oral and Maxillofacial Surgery, School of Stomatology, China Medical University, \\ Liaoning Institute of Dental Research, Shenyang, Liaoning 110002, P.R. China
}

Received December 31, 2014; Accepted October 6, 2015

DOI: $10.3892 / \mathrm{mmr} .2015 .4498$

\begin{abstract}
The aim of the present study was to examine the biocompatibility of transforming growth factor- $\beta 1$-silk fibroin-chitosan (TGF- $\beta 1-S F-C S$ ) scaffolds. In order to provide an ideal scaffold for use in bone tissue engineering, TGF- $\beta 1$ was introduced into the SF-CS scaffold in order to reconstruct a three dimensional scaffold, following which hFOB1.19 osteoblast cells were seeded onto TGF- $\beta 1-S F-C S$ and SF-CS scaffolds. On the TGF- $\beta 1-S F-C S$ and SF-CS scaffolds, the cell adhesion rate increased in a time-dependent manner. Scanning electron microscopy revealed that the cells grew actively and exhibited normal morphological features with multiple fissions, and granular and filamentous substrates were observed surrounding the cells. In addition, the cell microfilaments were closely connected with the scaffolds. The cells exhibited attached growth on the surfaces of the scaffolds, however, the growth also extended into the scaffolds. Cell Counting Kit- 8 and ALP analyses revealed that TGF- $\beta 1$ significantly promoted the growth and proliferation of the hFOB1.19 osteoblast cells in the SF-CS scaffolds, and the enhancement of osteoblast cell proliferation and activity by TGF- $\beta 1$ occurred in a time-dependent manner. The TGF- $\beta 1-S F-C S$ composite material may offer potential as an ideal scaffold material for bone tissue engineering.
\end{abstract}

\section{Introduction}

Bone is a highly specialized tissue comprising a network of extracellular matrix components $(1,2)$. Bone exhibits a poor capacity for self-repair; therefore, even small defects may require surgery (3). Tissue engineering approaches using autologous cells and various scaffolds are becoming

Correspondence to: Professor Xu-Kai Wang, Department of Oral and Maxillofacial Surgery, School of Stomatology, China Medical University, Liaoning Institute of Dental Research, 117 Nan Jing North Street, Heping, Shenyang, Liaoning 110002, P.R. China E-mail: wangxukai757892@sina.com

Key words: silk fibroin, chitosan, bone tissue engineering, osteoblast cell, transforming growth factor- $\beta 1$ a promising alternative to conventional surgery. A combinatorial approach for treating large bone defects includes seeding cells, growth factors and biomaterials used in bone tissue engineering, which can enhance the success of cell therapy (4-7). Several scaffolds fabricated from natural or synthetic biomaterials have been suggested for use in bone tissue engineering. Selection of an appropriate biomaterial is important, as the behaviors and fates of cells are markedly affected by the structure and components of the biomaterial (8).

Growth factors have been shown to be critical in the induction and maintenance of osteoblast cell phenotype, and are active in the regulation of cell proliferation and differentiation in bone tissue engineering (9). Transforming growth factor- $\beta 1$ (TGF- $\beta$ ) is the most abundant cytokine in bone and, due to its abundance $(200 \mathrm{mg} / \mathrm{kg})$, it may be central in bone turnover (10). TGF- $\beta 1$ is critical in bone formation, mineral storage and hematopoietic cell generation. Of the TGF- $\beta$ superfamily, TGF- $\beta 1$ exhibits the most marked chemotactic effect towards human osteoblasts, and application of this cytokine in a dog model was observed to enhance mechanical fixation, bone ingrowth and gap bone formation in the presence of unloaded implants surrounded by a gap (11); an effect, which was pronounced with low concentrations of TGF- $\beta 1$, but not with higher concentrations (12). TGF- $\beta 1$ has been widely used to promote the osteogenesis of bone marrow stromal cells in a variety of in vitro culture systems, by supplying it in the medium continuously for $>4$ weeks (13-15). Arious technologies have been engineered with the aim of local delivery and controlled release of an appropriate concentration of these growth factors in vitro (16-22). Therefore, the controlled administration of TGF- $\beta 1$ may represent an emerging tissue engineering technology, which may modulate cellular responses to encourage bone regeneration of skeletal defects $(23,24)$.

Osteoblasts are mononucleated cells, which are responsible for bone formation. They arise from osteoblastic precursors located in the deeper layer of periosteum and the bone marrow, and produce a matrix of osteoid, which is composed predominantly of type I collagen (25). TGF- $\beta 1$ has a variety of widely recognized roles in bone formation. For example, TGF- $\beta 1$ enhances osteoblast proliferation (26), and it also enhances the production of extracellular bone matrix protein by osteoblasts in the early stages of osteoblast differentiation (27). 
The silk fibroin-chitosan (SF-CS) scaffold has been recognized as a suitable material for applications in orthopedics and maxillofacial surgery due to it being biodegradable, biocompatible and exhibiting osteoconductive properties (28-30). In our previous study, SF and CS were combined into a three dimensional (3D) scaffold to provide unique chemical, structural and mechanical properties, for utilization in bone tissue engineering and regenerative applications. The investigation found that the most appropriate proportion of CS and SF was 5:5 for bone tissue engineering (31).

In the present study, TGF- $\beta 1$ was introduced into the SF-CS scaffold to reconstruct a 3D scaffold for the first time, to the best of our knowledge. The subsequent aim was to examine the application and biocompatibility of the TGF- $\beta 1-S F-C S$ $3 \mathrm{D}$ scaffolds in meeting the requirements of bone tissue engineering scaffolds. The effect of the TGF- $\beta 1$-SF-CS composite scaffolds on hFOB1.19 osteoblast cell morphology, differentiation and function remain to be elucidated, and have not been investigated previously. TGF- $\beta 1$ was used in the present study to evaluate the suitability of the SF-CS scaffolds as matrices, using hFOB1.19 osteoblast cells. The cellular activity, viability, and biochemistry were analyzed for bone tissue engineering. The critical effects of the materials in morphogenesis were analyzed from the in vitro response to identify the clinical relevance of the SF-CS scaffold.

\section{Materials and methods}

Materials. Raw silk was purchased from Silk Co., Ltd. (Nanchong, Sichuan, China). Chitosan was purchased from Tongxing Company (Jiangsu, China). TGF- $\beta 1$ (100 ng/bottle) was purchased from ProSpec-Tany TechnoGene, Ltd. (Rehovot, Israel). hFOB1.19 osteoblast cells were purchased from BioHermes Co., Ltd. (Shanghai, China). $\mathrm{NaHCO}_{3}, \mathrm{CaCl}_{2}$ and ethanol were purchased from Nanjing Jiancheng Bioengineering Institute, (Nanjing, China). All other chemicals and reagents were of analytical grade, unless specified otherwise.

Preparation of the TGF- $\beta 1-S F-C S$ and SF-CS scaffolds. The Bombyx mori silk fibers were treated twice with $0.5 \%(\mathrm{w} / \mathrm{w})$ $\mathrm{NaHCO}_{3}$ solution at $100^{\circ} \mathrm{C}$ for $30 \mathrm{~min}$, and were then rinsed with $70^{\circ} \mathrm{C}$ distilled water to remove the sericin for $30 \mathrm{~min}$, followed by drying at $37^{\circ} \mathrm{C}$. The degummed silk was dissolved in a solvent mixture of $\mathrm{CaCl}_{2}(44.4 \mathrm{~g}) / \mathrm{CH}_{3} \mathrm{CH}_{2} \mathrm{OH}(46 \mathrm{ml}) / \mathrm{H}_{2} \mathrm{O}$ $(57.5 \mathrm{ml})$ with a molar ratio of $1: 2: 8$, at $70^{\circ} \mathrm{C}$ for $6 \mathrm{~h}$, and was filtered to obtain the SF solution. Following dialysis in cellulose dialysis tubing (molecular weight cut-off; $\mathrm{MWCO}=50,000$; Nanjing Jiancheng Biotechnology Institute, Nanjing, China) against distilled water for 3 days, with the water replaced every $12 \mathrm{~h}$. The final concentration of SF used was $8 \%$.

The CS solutions were prepared by dissolving high molecular-weight CS $(82.7 \%$ deacetylation; Tongxing Company) at $3.66 \%(\mathrm{w} / \mathrm{v})$ in $2 \%$ acetic acid (Nanjing Jiancheng Biotechnology Institute). The final concentration of CS used was $2 \%$.

TGF- $\beta 1$ solution was prepared by dissolving $100 \mathrm{ng}$ TGF- $\beta 1$ in $1 \mathrm{ml}$ deionized sterile water $(100 \mathrm{ng} / \mathrm{ml})$.

The SF/CS blend solution $(100 \mathrm{ml})$ with a SF/CS weight ratio of 5:5, was prepared in the same solvent at $10 \mathrm{wt} \%$ (combined weight of CS and SF). Following dialysis in cellulose dialysis tubing $(\mathrm{MWCO}=50,000)$ against distilled water for 3 days, with water replaced every $12 \mathrm{~h}$, the CS and SF solution was obtained. Subsequently, $1 \mathrm{ml}$ TGF- $\beta 1$ solution was added and stirred in a magnetic stirrer (JB-2A; Bante Instruments Limited, Shanghai, China) for $50 \mathrm{~min}$. The mixture of CS, SF and TGF- $\beta 1$ was then added into a 24-hole teflon culture plate. The CS, SF and TGF- $\beta 1$ solution was then lyophilized (VFD-2000; Boyikang Laboratory Instruments Co., Ltd., Beijing, China) to obtain the TGF- $\beta 1-$ SF-CS scaffold. The SF-CS scaffolds were prepared using the same method.

To improve water stability, the dry TGF- $\beta 1$-SF-CS and SF-CS scaffolds were treated in methanol solution (concentration $<10 \%$ ) for $2 \mathrm{~h}$ to crystallize the SF content and neutralize the CS content. The TGF- $\beta 1-S F-C S$ and SF-CS scaffolds were then lyophilized to remove the excess methanol.

hFOB1.19 osteoblast cell culture. The hFOB1.19 osteoblast cells, supplied by BioHermes, were cultured in DMEM/F12 medium supplemented with $10 \%$ fetal bovine serum (ProSpec-Tany TechnoGene, Ltd.), $200 \mathrm{mM} / 1$ glutamine, $2 \mathrm{mg} / \mathrm{ml}$ sodium bicarbonate and $100 \mathrm{mg} / \mathrm{ml}$ penicillin/streptomycin (ProSpec-Tany TechnoGene, Ltd.). The cells were cultured in $25 \mathrm{~cm}^{2}$ flasks at $37^{\circ} \mathrm{C}$ in a humidified atmosphere of $5 \% \mathrm{CO}_{2}$. Confluent monolayers were split by treatment with phosphate-buffered saline (PBS) and $0.05 \%$ trypsin/EDTA solution (Nanjing Jiancheng Biotechnology Institute), and the culture medium was replaced every 2 days.

The samples were sterilized with $75 \%$ alcohol under ultraviolet light overnight, and were then rinsed extensively three times with sterile PBS. Prior to cell culture, the scaffolds were pre-soaked by immersion in DMEM for $12 \mathrm{~h}$ in the $37^{\circ} \mathrm{C}$ incubator.

The hFOB1.19 osteoblast cells were cultured onto the TGF- $\beta 1$-SF-CS scaffolds, SF-CS scaffolds and 24-well tissue culture plate wells as a control group $(\mathrm{n}=3$; diameter $15 \mathrm{~mm}$; height $13 \mathrm{~mm}$ ) for 3 and 6 days at $37^{\circ} \mathrm{C}$ under an atmosphere of $5 \% \mathrm{CO}_{2}$ and $95 \%$ air, with an original cell culture density of 4,000 cells/well.

Cell morphology. The morphological features of the osteoblast cells on the TGF- $\beta 1$-SF-CS scaffold and SF-CS scaffold were observed on days 1, 3 and 7 of culture using a scanning electron microscope (SEM; TM3000; Hitachi, Ltd., Tokyo, Japan). The samples were washed with PBS and fixed with 3.0\% glutaraldehyde (Nanjing Jiancheng Biotechnology Institute) at $4^{\circ} \mathrm{C}$ for $4 \mathrm{~h}$. Subsequently, the samples were dehydrated through a series of graded ethanol solutions $(30,50,70,80$, 90, 95 and 100\%), air-dried overnight, and sputtered with gold for SEM observation. Adherent cell morphology, patterns of cellular adherence with respect to structural features of the TGF- $\beta 1-S F-C S$ scaffold and SF-CS scaffold, cell-cell interactions, and adherent cell density were assessed.

Adhesion of cells. The cells, which had adhered to the TGF- $\beta 1-S F-C S$ scaffold, SF-CS scaffold and control group were harvested, and the concentration was adjusted to $1 \times 10^{4} / \mathrm{ml}$. The cells were placed in cell culture plates, which were pre-coated with the TGF- $\beta 1$-SF-CS scaffold and SF-CS 


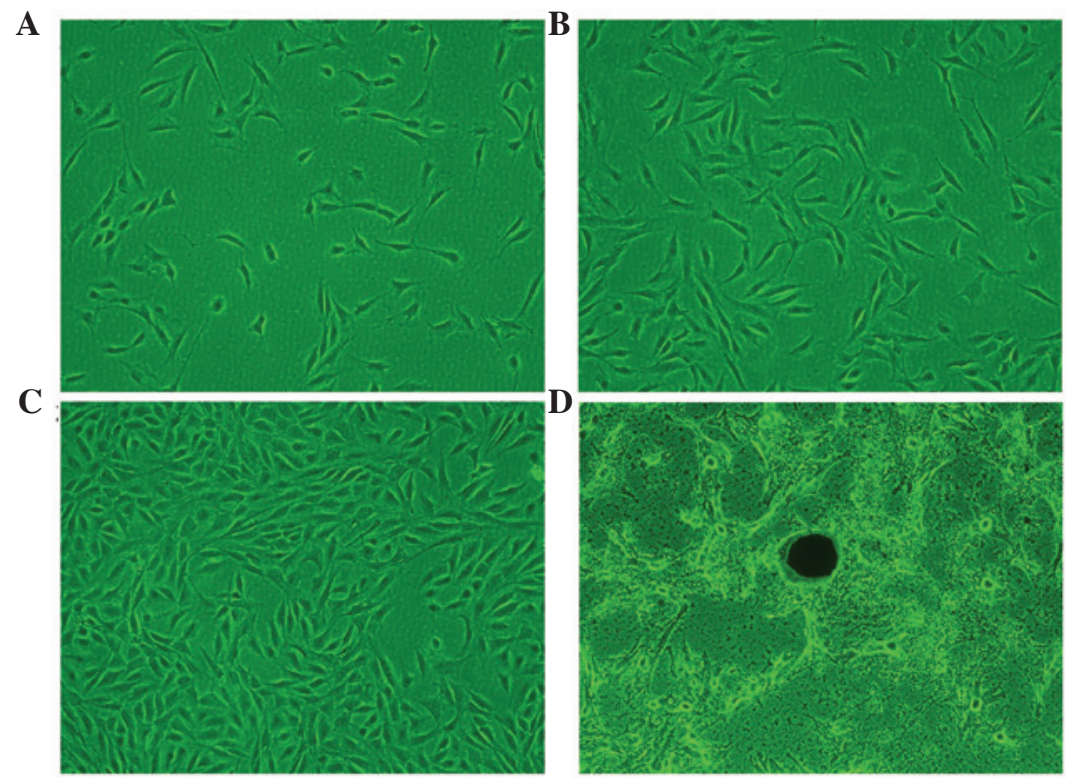

Figure 1. Cell morphology of the hFOB1.19 cells, examined under a light-inverted microscope (magnification, x100). Cell morphology was examined following culture for (A) 1 day, hFOB1.19 exhibited a fibroblast-like, spindle-shaped morphology; (B) 3 days, the majority of the cells had become large and flattened, with a polygonal or triangular shape; (C) 6 days, the cells exhibited adequate growth and active proliferation, with an increased density observed; and (D) 18 days, mineral nodules were formed.

scaffold (1 ml per well). Cells cultured in culture plates with no scaffold served as controls. A total of six parallel wells were used for each group. The cells were cultured in an incubator at $37^{\circ} \mathrm{C}$ with $5 \% \mathrm{CO}_{2}$. The numbers of non-adhered cells were quantified at $1,2,4,8$ and $24 \mathrm{~h}$.

The cell adhesion rate was calculated according to the following formula: Adhesion rate $(\%)=($ number of seeded cells - non-adhered cells) / number of seeded cells x 100.

Cell Counting Kit-8 (CCK-8) assay. In order to examine the survival of the grafted cells, the cell viability and proliferation rates were determined using a CCK-8 assay (Nanjing Jiancheng Biotechnology Institute). Briefly, following culture of the samples for 1, 3,5 and 7 days, the culture medium was replaced with serum-free culture medium containing CCK-8 $(0.5 \mathrm{mg} / \mathrm{ml})$. Following culture for $4 \mathrm{~h}$, the samples were transferred onto a 96-well plate. The absorbance was measured at $450 \mathrm{~nm}$ using an ELISA reader (Bio-Rad 550 Bio-Rad Laboratories, Inc., Hercules, CA, USA).

Alkaline phosphatase (ALP) activity. The activities of intracellular ALP in the scaffolds and control group were measured using an ALP assay kit (Nanjing Jiancheng Bioengineering Institute). Briefly, the samples were cultured 1, 4, 7 and 10 days, and then washed with PBS three times. The cells in the samples and control were then immersed in $500 \mu 1$ of cell lysis solution containing $0.1 \%$ Triton X-100 (Nanjing Jiancheng Biotechnology Institute) and $5 \mathrm{mM} \mathrm{MgCl}{ }_{2}$ (Nanjing Jiancheng Biotechnology Institute) at room temperature overnight. The whole solution was transferred into a tube and centrifuged at $28,340 \mathrm{x} \mathrm{g}$ for $10 \mathrm{~min}$ at $4^{\circ} \mathrm{C}$. ALP activity was measured by mixing $50 \mu \mathrm{l}$ of supernatant with $50 \mu \mathrm{l}$ p-nitrophenyl phosphate $(5 \mathrm{mM})$ in $150 \mathrm{mM}$ 2-amino-2-methyl-1-propanol buffer solution at room temperature for $30 \mathrm{~min}$ in the dark. Following the incubation period, the reaction was terminated by adding
$50 \mu \mathrm{l}$ of $0.2 \mathrm{~N} \mathrm{NaOH}$ to denature the ALP. The optical density (OD) was then measured at $520 \mathrm{~nm}$ using an ELISA reader (Bio-Rad Model 550; Bio-Rad Laboratories, Inc.).

Statistical analysis. All quantitative data are expressed as the mean \pm standard deviation. Statistical analyses were performed using the statistical program, SPSS 17 (SPSS, Inc., Chicago, IL, USA). The results were analyzed using one-way analysis of variance (ANOVA) with Student's $t$-test. $\mathrm{P}<0.05$ were considered to indicate a statistically significant difference. Prior to results being analyzed using one-way ANOVA, all quantitative data were confirmed as normally distributed.

\section{Results}

Cell morphology. Cell morphology was examined using a light-inverted microscope (CKX41; Olympus Corporation, Tokyo, Japan) (Fig. 1), in which the hFOB1.19 osteoblast cells demonstrated a high rate of survival and rapid proliferation.

In the primary cells, the hFOB1.19 osteoblast cells exhibited a round morphology. After $12 \mathrm{~h}$, the hFOB1.19 cells were sparsely attached to the culture flasks, and exhibited a fibroblast-like, spindle-shaped morphology. As the cell number increased and the cells continued to grow, a substantial number of cells on day 3 had adhered to the surface of the culture flask, and the majority of the cells had become large and flattened, with a polygonal or triangular shape. After 6 days of culture, the cells showed adequate growth and exhibited active proliferation. A higher density was observed in the primary and transformed cells, which did not change throughout the different passages. The osteoblast cells had become well-formed mineral nodules at day 18 (Fig. 1).

Adhesion rate of the hFOB1.19 osteoblast cells is not altered by TGF- $\beta 1$. Following culture for 1, 3 and $6 \mathrm{~h}$, cell adhesion 
rate increased with increasing duration in the three groups. The adhesion rates in the TGF- $\beta 1-S F-C S$ group and SF-CS group were higher, compared with that in the control group $(\mathrm{P}<0.01$; Fig. 2). After $1 \mathrm{~h}$, the adhesion rate of the major populations of cells in the SF-CS scaffolds were almost the same as those in the TGF- $\beta 1-S F-C S$ scaffolds, with no significant differences between the scaffold groups $(\mathrm{P}>0.05)$. The rapid time-course of osteoblast cell adhesion to the SF-CS and TGF- $\beta 1-S F-C S$ scaffolds was significant, exhibiting $29 \%$ adhesion by 60 min post-seeding. After 3 and $6 \mathrm{~h}$, there were significant increases in the numbers of adherent cells, compared with the numbers after $1 \mathrm{~h}$ (Fig. 2). The adhesion rates in the TGF- $\beta 1-S F-C S$ scaffold and SF-CS scaffold groups were significantly higher, compared with that in the control group $(\mathrm{P}<0.01)$, however, there remained no significant differences between the two scaffold groups ( $\mathrm{P}>0.05)$. These results confirmed that the SF-CS scaffold increased the adhesion of the osteoblasts cells. The results also revealed that TGF- $\beta 1$ did not promote hFOB1.19 osteoblast cell adhesion in the SF-CS scaffolds.

SEM images of hFOB1.19 cells cultured with the TGF- $\beta$-SF-CS scaffolds indicate biocompaitibilty. The SEM images showed randomly distributed cells on the surface and inside the TGF- $\beta 1-S F-C S$ scaffold and SF-CS scaffold.

On examining the growth of cells on the scaffold at 1 day, scattered round cells had adhered to the scaffold and a large number of particles were observed on the cell surface. Cell microfilaments were connected with the scaffold material (Fig. 3A).

After 3 days, a large number of the cells had adhered to the surface and pores of the scaffold. The cell aggregates had become enlarged and actively proliferating. The SEM results showed that the single round cells had become polygonal or triangular in shape. Granular and filiform substances were observed around the cells, and cell microfilaments and pseudopodia were tightly connected to the scaffold (Fig. 3B).

After 7 days, an increased number of cells had adhered to the surface and pores of the scaffold, compared with the number at 3 days, and the cells had grown and proliferated well. The cells exhibited a typical osteoblast cell morphology, and adhered tightly on the scaffold surface or inside via the formation of lamellipodia and filopodia, indicative of cell spreading. A number of cells present were observe to extend towards other cells in the culture. The cells were well attached to the TGF- $\beta 1-S F-C S$ scaffolds and appeared to have spread. The majority of the cells had collected together to form cellular aggregations, which is crucial for the viability and function of hFOB1.19 cells in vitro. The SF-CS scaffolds showed fewer or more sparse attachment of cells, compared with the TGF-ß1-SF-CS scaffolds (Fig. 3C).

TGF- $\beta 1$ promotes the proliferation of hFOB1.19 cells. The proliferation rats of the hFOB1.19 cells on the VEGF-SF-CS scaffolds, SF-CS scaffolds and control group cultured for 1, 3,5 and 7 days were compared using a CCK- 8 assay. The absorbance values for the TGF- $\beta 1-S F-C S$ scaffolds and SF-CS scaffolds gradually increased, indicating significant cell growth within the two scaffolds (Fig. 4). The hFOB1.19 cells cultured without scaffolds showed similar results. The

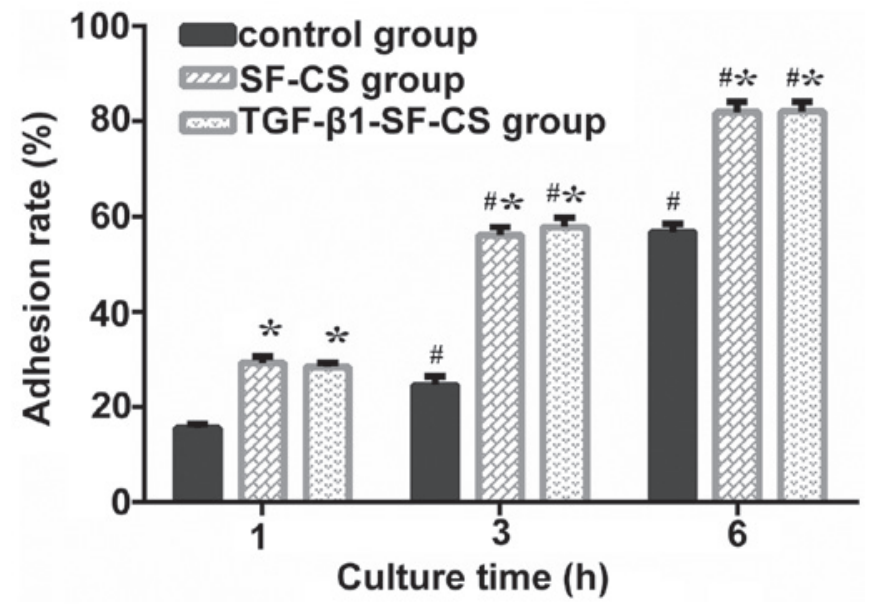

Figure 2. Adhesion rate of hFOB1.19 osteoblast cells cultured with the SF-CS scaffold, TGF- $\beta 1-S F-C S$ scaffold and the control. Data are expressed as the mean \pm standard deviation. ${ }^{*} \mathrm{P}<0.05$, vs. the control group; ${ }^{\prime \prime} \mathrm{P}<0.05$, vs. previous durations of the same scaffold group. TGF, transforming growth factor; SF, silk fibroin; CS, chitosan.

number of cells increased with culture duration in all three groups. hFOB1.19 cell proliferation was observed in the TGF- $\beta 1$-SF-CS scaffolds and SF-CS scaffolds, and there were no significant differences between these groups and the cells cultured in the control group after 1 day $(\mathrm{P}>0.05)$. However, after 3 days, the numbers of hFOB1.19 cells cultured in the TGF- $\beta 1-S F-C S$ scaffolds were higher than thoses cultured in the SF-CS scaffolds, and the numbers of hFOB1.19 cells cultured in the two scaffold groups were significantly higher, compared with the number of cells cultured without scaffolds $(\mathrm{P}<0.05)$.

TGF- $\beta 1$ promotes the activity of ALP in hFOB1.19 cells. The ALP activity of the hFOB1.19 cells cultured in the TGF- $\beta 1-S F-C S$ scaffolds, SF-CS scaffolds and control group are shown in Fig. 5. In the measurements of total ALP activity during the culture period between days 1 and 4, no significant difference in OD values were identified between the TGF- $\beta 1-S F-C S, S F-C S$ and control groups $(\mathrm{P}>0.05)$. However, between days 4 and 10, significant differences in the $\mathrm{OD}$ values were found between the scaffold groups and the control group $(\mathrm{P}<0.01)$. The OD values in the TGF- $\beta 1-\mathrm{SF}-\mathrm{CS}$ groups were the highest. This suggested that TGF- $\beta 1$ had an effect on the activity of the hFOB1.19 cells. As the duration of culture increased between days 4 and 10, the growth trend of the OD values in three groups increased rapidly, and the OD values peaked after 10 days.

\section{Discussion}

The development of biomimetic scaffolds to enhance bone-formation has largely focused on altering the chemical composition of scaffolds. Therefore, the present study combined SF-CS scaffolds with the TGF- $\beta 1$ growth factor, in order to promote bone-formation. The results of the present study demonstrated that the SF-CS scaffolds provided a suitable environment for osteoblast cell proliferation and differentiation in the presence of TGF- $\beta 1$ in vitro. 
A

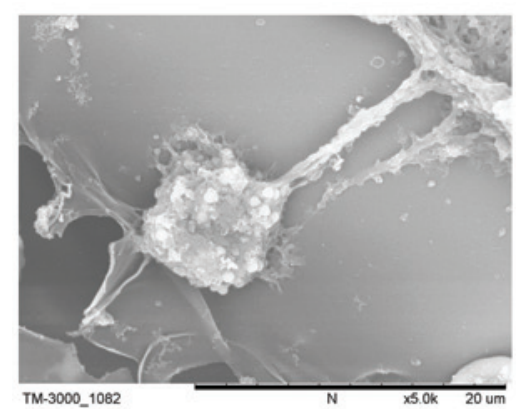

B

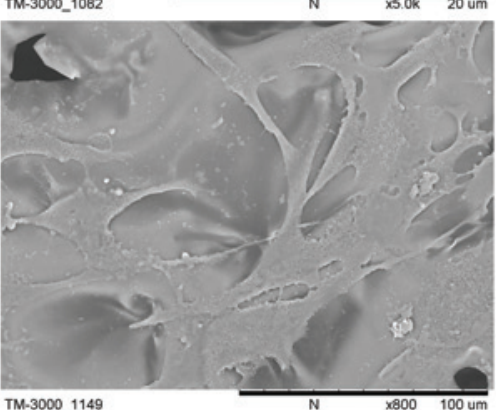

C

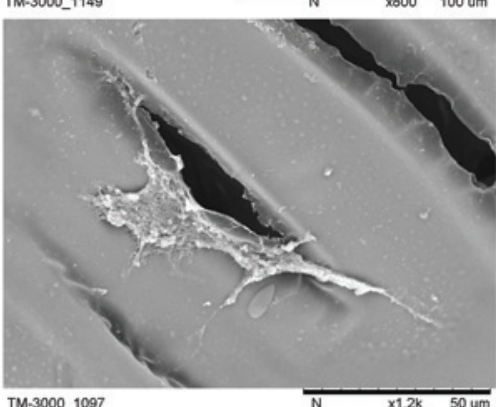

D

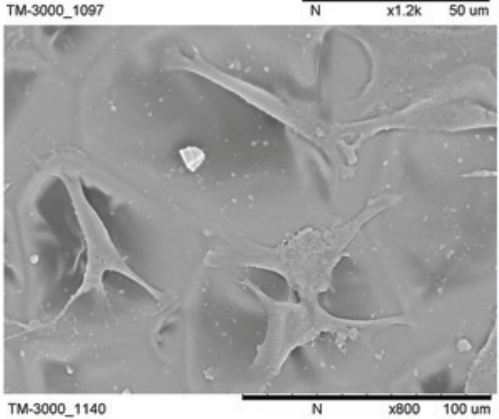

Figure 3. Scanning electron microscopy images of the hFOB1.19 cells cultured with the transforming growth factor- $\beta 1$-silk fibroin-chitosan scaffold for (A) 1 day, scattered round cells had adhered to the scaffold and a large number of particles were observed on the cell surface, cell microfilaments were connected with the scaffold material; (B) 3 days, single round cells had become polygonal or triangular in shape, granular and filiform substances were observed around the cells and cell microfilaments and pseudopodia were tightly connected to the scaffold; and (C) 7 days, the cells exhibited a typical osteoblast cell morphology, and adhered tightly on the scaffold surface or inside via the formation of lamellipodia and filopodia, indicative of cell spreading. A number of cells present were observed to extend towards other cells in the culture. (D) hFOB1.19 cells cultured with the SF-CS scaffold at 7 days, fewer and more sparse attachment of cells was observed compared with the TGF- $\beta 1$-SF-CS scaffolds. TGF- $\beta 1$, transforming growth factor- $\beta 1$; SF, silk fibroin; CS, chitosan.

The response of cells to TGF- $\beta 1$ varies depending on the dose, length of exposure and target tissue (32). A prolonged exposure and high dose of TGF- $\beta 1$ may result in pathological conditions, including extensive fibrosis, hypertrophic scarring and the formation of osteophytes $(32,33)$. An engineered system capable of inducing cell-mediated TGF- $\beta 1$ activation

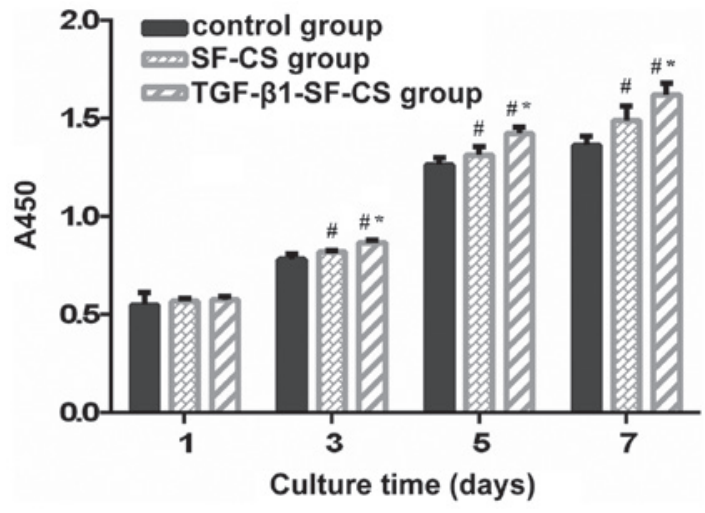

Figure 4. Cell Counting Kit-8 assay determination of the proliferation of hFOB1.19 cells. The TGF- $\beta 1-$ SF-CS scaffold promoted the proliferation of the hFOB1.19 cell significantly, compared with the SF-CS scaffold after 3 days. Data are expressed as the mean \pm standard deviation ${ }^{*} \mathrm{P}<0.05$, vs. the SF-CS group; " $\mathrm{P}<0.05$, vs. the control group. TGF- $\beta 1$, transforming growth factor- $\beta 1$; SF, silk fibroin; $C S$, chitosan.

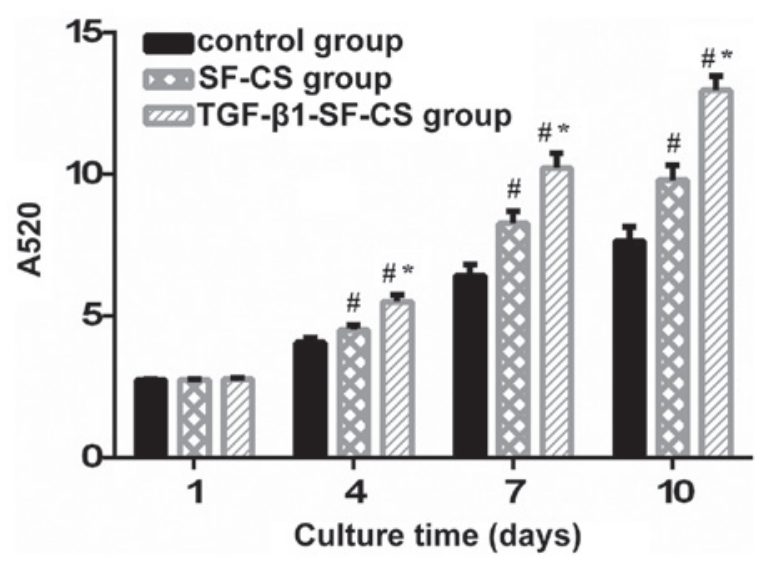

Figure 5. Alkaline phosphatase assay of the proliferation of hFOB1.19 cells cultured with different scaffolds and the control. The TGF- $\beta 1$-SF-CS scaffold promoted the proliferation of the hFOB1.19 cells significantly after 4 days, compared with the SF-CS group. Data are expressed as the mean \pm standard deviation. ${ }^{*} \mathrm{P}<0.05$, vs. the SF-CS group; ${ }^{*} \mathrm{P}<0.05$, vs. the control group. TGF- $\beta 1$, transforming growth factor- $\beta 1$; SF, silk fibroin; CS, chitosan.

can begin to address these problems through bone tissue engineering. The novel strategy investigated in the present study aimed to incorporate TGF- $\beta 1$ onto an SF-CS scaffold and allow osteoblast cells to sense and activate TGF- $\beta 1$, as required.

When fabricating the TGF- $\beta 1$-SF-CS scaffold for bone tissue engineering, it is critical to maintain the bioactivity of TGF- $\beta 1$ as, during the course of manufacture, TGF- $\beta 1$ bioactivity is most likely to be destroyed in lyophilization and methanol crosslinking. In lyophilization, the use of a cryoprotector may reduce or even prevent the effects of stress on the activity of the protein (34). Silk protein and chitosan can be used as cryoprotectors to maintain the activity of TGF- $\beta 1(35,36)$. Klibanov (37) reported that the conformation of proteins treated with low concentration methanol remain unchanged, and the covalent structure of the protein molecule is not destroyed. In the present study, the following measures were taking in constructing the TGF- $\beta 1-S F-C S$ scaffold to prevent the TGF- $\beta 1$ bioactivity from being 
destroyed: (i) Lyophilization temperature was set at $-40^{\circ} \mathrm{C}$, and silk and chitosan were used as cryoprotectors to further maintain TGF- $\beta 1$ activity; (ii) methanol concentration was $<10 \%$. Through ALP and CCK-8 assays, it was evident that no significant degradation of TGF- $\beta 1$ bioactivity had occurred.

In the present study, the SF-CS scaffold was manufactured in aqueous solution to incorporate the active TGF- $\beta 1$ molecule without damaging TGF- $\beta 1$ activity. Mandal and Kundu (38) utilized lyophilization to prepare a 3D silk fibroin scaffold in bovine serum albumin, and then examined its in vitro release and performance. The results of the ALP and CCK- 8 assays in the present study result revealed that, in the TGF- $\beta 1$-SF-CS scaffold, TGF- $\beta 1$ was evenly and continuously released within a certain period.

In the present study, osteoblast cell morphology was investigated using SEM to further evaluate the biocompatibility of the SF-CS and TGF- $\beta 1$-SF-CS scaffolds. The seeding of hFOB1.19 on TGF- $31-$ SF-CS scaffolds up to 7 days resulted in polygonal or triangular cell morphologies, similar to what is typically observed in standard cell culture flasks. These observations confirmed cell survival and proliferation on the TGF- $\beta 1$-SF-CS scaffolds, assuring its biocompatibility. The evidence of cell-cell interactions and cell spreading are considered to be signs of healthy cells and indicative of a non-cytotoxic response of the cells on TGF- $\beta 1-S F-C S$ scaffolds $(39,40)$.

The time course of the adhesion of osteoblast cells to the SF-CS and TGF- $\beta 1$-SF-CS scaffolds clearly demonstrated that adhesion of the hFOB1.19 to the SF-CS and TGF- $\beta 1-S F-C S$ scaffolds occurred within minutes. The rapid time-course of osteoblast cell adhesion to the SF-CS and TGF- $\beta 1-S F-C S$ scaffolds was significant, exhibiting $29 \%$ adhesion by $60 \mathrm{~min}$ post-seeding. The adhesion rate of the hFOB1.19 cells in the TGF- $\beta 1-S F-C S$ group and SF-CS group significantly exceeded those in the control group $(\mathrm{P}<0.05)$, although no statistically significant differences $(\mathrm{P}>0.05)$ were observed between the SF-CS and TGF- $\beta 1-S F-C S$ scaffold groups. Previous studies have indicated that SF-CS scaffolds increase the adhesion and growth of osteoblast cells. The observations in the present study achieved the primary objective in determining whether SF-CS scaffolds have the potential to establish an adhesive interface with osteoblast cells in vitro. The results also confirmed that TGF- $\beta 1$ was unable to promote the adhesion of hFOB1.19 osteoblast cells to the SF-CS scaffolds.

The levels of cell growth and proliferation on the scaffolds and control group were assessed in the present study using CCK-8 and ALP assays in vitro. It was observed that the absorbance index of the assessed groups increased with the increase in culture duration. After 1 day, no statistically significant differences $(P>0.05)$ were observed in cell activity among the three groups. The activities of the hFOB1.19 cells cultured on the TGF- $\beta 1-S F-C S$ and SF-CS scaffolds were higher than that of the cells cultured in the control group after 3 days in culture, which suggested that the scaffolds were beneficial to cell development. The number of osteoblast cells on the TGF- $\beta 1$-SF-CS scaffolds were significantly higher, compared with those on the SF-CS scaffolds. These results indicated that TGF- $\beta 1$ significantly promoted the attachment and proliferation of the osteoblast cells. The results of the present study also support evidence from in vitro experiments that TGF- $\beta 1$ may regulate bone formation through a direct effect on osteoblasts. It has been reported that human TGF- $\beta 1$ binds to osteoblasts in culture, and is capable of inducing migration and alkaline phosphatase activity (41). The results of the present study indicated differences in the activities of the osteoblast cells in the different scaffold groups. The reason for the differences in the production of extracellular matrices in the different scaffolds may be due to the differences in the chemical compositions of the matrices.

The enhancement of osteoblast cell proliferation and activity by TGF- $\beta 1$ was time-dependent. TGF- $\beta 1$ did not significantly promote the activity or proliferation of osteoblast cells during the first 3 days of culture, however, it had a marked effect when cultured between days 3 and 10, demonstrating that the effect of TGF- $\beta 1$, which promotes the activity and proliferation of osteoblast cells, was time-dependent. These results indicated that the TGF- $\beta 1$ delivery strategies have a marked affect on osteogenic differentiation and require consideration when designing such a delivery system.

Previous results have indicated that this 3D environment, coupled with growth factor application, may be key in recreating an in vitro tissue-specific microenvironment for improving bone repair strategies. The results of the present study support the suggested that TGF- $\beta 1$ is important for promoting hFOB1.19 osteoblast cell extracellular matrix production. Based on the observations in the present study following 10 days of culture, future bone tissue engineering investigations can be performed to focus on how TGF- $\beta 1$ combines with the SF-CS scaffold, whether the sustained release of TGF- $\beta 1$ is maintained and enhanced over longer durations, and whether the culture of different type of cells on the SF-CS-SF-CS scaffolds yield similar outcomes.

In conclusion, the results of the present study confirmed that the direct effects of TGF- $\beta 1$ on osteoblast cells were an increase in the proliferation, migration, differentiation and survival of the cells. The TGF- $\beta 1$-SF-CS scaffolds were biocompatible and had no negative effects on the hFOB1.19 osteoblast cells in vitro. The SF-CS composite material may offer potential as an ideal scaffold material for bone tissue engineering.

\section{Acknowledgements}

The current study was supported by the Science and Technology Plan Project of Liaoning Province (grant. no. 20 12-B-00002012225082).

\section{References}

1. Vacanti JP and Langer R: Tissue engineering: The design and fabrication of living replacement devices for surgical reconstruction and transplantation. Lancet 354 (Supp 1): SI32-SI34, 1999.

2. Scheller EL, Krebsbach PH and Kohn DH: Tissue engineering: State of the art in oral rehabilitation. J Oral Rehabil 36: 368-389, 2009.

3. Hankenson KD, Dishowitz M, Gray C and Schenker M: Angiogenesis in bone regeneration. Injury 42: 556-561, 2011.

4. Marsell R and Einhorn TA: The biology of fracture healing. Injury 42: 551-555, 2011.

5. Muschler GF, Nakamoto C and Griffith LG: Engineering principles of clinical cell-based tissue engineering. J Bone Joint Surg Am 86-A: 1541-1558, 2004. 
6. Grayson WL, Chao PH, Marolt D, Kaplan DL and Vunjak-Novakovic G: Engineering custom-designed osteochondral tissue grafts. Trends Biotechnol 26: 181-189, 2008.

7. Vunjak-Novakovic G, Meinel L, Altman G and Kaplan D: Bioreactor cultivation of osteochondral grafts. Orthod Craniofac Res 8: 209-218, 2005

8. Adams JC and Watt FM: Regulation of development and differentiation by the extracellular matrix. Development 117: 1183-1198, 1993.

9. Zhang LH and Zhang QQ: Study on the osteoblast and the growth factors of bone tissue engineering. Zhongguo Yi Xue Ke Xue Yuan Xue Bao 23: 631-637, 2001 (In Chinese).

10. Bonewald LF and Dallas SL: Role of active and latent transforming growth factor beta in bone formation. J Cell Biochem 55: 350-357, 1994.

11. Saitta B, Passarini J, Sareen D, Ornelas L, Sahabian A, Argade S, Krakow D, Cohn DH, Svendsen CN and Rimoin DL: Patient-derived skeletal dysplasia induced pluripotent stem cells display abnormal chondrogenic marker expression and regulation by BMP2 and TGF- $\beta 1$. Stem Cells Dev 23: 1464-1478, 2014.

12. Lind M: Growth factor stimulation of bone healing. Effects on osteoblasts, osteomies and implants fixation. Acta Orthop Scand Suppl 283: 2-37, 1998.

13. Connelly JT, Wilson CG and Levenston ME: Characterization of proteoglycan production and processing by chondrocytes and BMSCs in tissue engineered constructs. Osteoarthritis Cartilage 16: 1092-1100, 2008

14. Mouw JK, Connelly JT, Wilson CG, Michael KE and Levenston ME: Dynamic compression regulates the expression and synthesis of chondrocyte-specific matrix molecules in bone marrow stromal cells. Stem Cells 25: 655-663, 2007.

15. Johnstone B, Hering TM, Caplan AI, Goldberg VM and Yoo JU: In vitro chondrogenesis of bone marrow-derived mesenchymal progenitor cells. Exp Cell Res 238: 265-272, 1998.

16. Vehof JW, Haus MT, de Ruijter AE, Spauwen PH and Jansen JA: Bone formation in transforming growth factor beta-I-loaded titanium fiber mesh implants. Clin Oral Implants Res 13: 94-102, 2002.

17. Holland TA, Tessmar JK, Tabata Y and Mikos AG: Transforming growth factor-beta 1 release from oligo (poly(ethylene glycol) fumarate) hydrogels in conditions that model the cartilage wound healing environment. J Control Release 94: 101-104, 2004.

18. Motoyama M, Deie M, Kanaya A, Nishimori M, Miyamoto A, Yanada S, Adachi N and Ochi M: In vitro cartilage formation using TGF-beta-immobilized magnetic beads and mesenchymal stem cell-magnetic bead complexes under magnetic field conditions. J Biomed Mater Res A 92: 196-204, 2010.

19. Park H, Temenoff JS, Tabata Y, Caplan AI, Raphael RM, Jansen JA and Mikos AG: Effect of dual growth factor delivery on chondrogenic differentiation of rabbit marrow mesenchymal stem cells encapsulated in injectable hydrogel composites. J Biomed Mater Res A 88: 889-897, 2009.

20. Fischer U, Hempel U, Becker D, Bierbaum S, Scharnweber D, Worch $\mathrm{H}$ and Wenzel KW: Transforming growth factor betal immobilized adsorptively on Ti6Al4V and collagen type I coated Ti6Al4 V maintains its biological activity. Biomaterials 24: 2631-2641, 2003

21. Dickhut A, Dexheimer V, Martin K, Lauinger R, Heisel C and Richter W: Chondrogenesis of human mesenchymal stem cells by local TGF-beta delivery in a biphasic resorbable carrier. Tissue Eng Part A 16: 453-464, 2010.

22. Park JS, Yang HJ, Woo DG, Yang HN, Na K and Park KH: Chondrogenic differentiation of mesenchymal stem cells embedded in a scaffold by long-term release of TGF-beta 3 complexed with chondroitin sulfate. J Biomed Mater Res A 92: 806-816, 2010.

23. Murphy CM, O'Brien FJ, Little DG and Schindeler A: Cell-scaffold interactions in the bone tissue engineering triad. Eur Cell Mater 26: 120-132, 2013
24. Roberts AB and Sporn MB: Physiological actions and clinical applications of transforming growth factor-beta (TGF-beta). Growth Factors 8: 1-9, 1993.

25. D'Ippolito G, Schiller PC, Ricordi C, Roos BA and Howard GA: Age-related osteogenic potential of mesenchymal stromal stem cells from human vertebral bone marrow. J Bone Miner Res 14: 1115-1122, 1999.

26. Kassem M, Kveiborg M and Eriksen EF: Production and action of transforming growth factor-beta in human osteoblast cultures: Dependence on cell differentiation and modulation by calcitriol. Eur J Clin Invest 30: 429-437, 2000.

27. Alliston T, Choy L, Ducy P, Karsenty G and Derynck R: TGF-beta-induced repression of CBFA1 by Smad3 decreases cbfa1 and osteocalcin expression and inhibits osteoblast differentiation. EMBO J 20: 2254-2272, 2001

28. Park SJ, Lee KY, Ha WS and Park SY: Structural changes and their effect on mechanical properties of silk fibroin/chitosan blends. Journal of Applied Polymer Science 74: 2571-2575, 1999.

29. El Sayed K, Marzahn U, John T, Hoyer M, Zreiqat H, Witthuhn A, Kohl B, Haisch A and Schulze-Tanzil G: PGA-associated heterotopic chondrocyte cocultures: Implications of nasoseptal and auricular chondrocytes in articular cartilage repair. J Tissue Eng Regen Med 7: 61-72, 2013.

30. De Santis R, Gloria A, Russo T, et al: A basic approach toward the development of nanocomposite magnetic scaffolds for advanced bone tissue engineering. Journal of Applied Polymer Science 122: 3599-3605, 2011.

31. Gobin AS, Froude VE and Mathur AB: Structural and mechanical characteristics of silk fibroin and chitosan blend scaffolds for tissue regeneration. J Biomed Mater Res A 74: 465-473, 2005 .

32. Saharinen J, Hyytiäinen M, Taipale J and Keski-Oja J: Latent transform-ing growth factor-beta binding proteins (LTBPs)-structural extracellular matrix proteins for targeting TGF-beta action. Cytokine Growth Factor Rev 10: 99-117, 1999.

33. Mierisch CM, Cohen SB, Jordan LC, Robertson PG, Balian G and Diduch DR: Transforming growth factor-beta in calcium alginate beads for the treat-ment of articular cartilage defects in the rabbit. Arthroscopy 18: 892-900, 2002.

34. Haines AH: Non-equivalence of D- and L-trehalose in stabilising alkaline phosphatase against freeze-drying and thermal stress. Is chiral recognition involved? Org Biomol Chem 4: 702-706, 2006.

35. Kreilgaard L, Jones LS, Randolph TW, Frokjaer S, Flink JM, Manning MC and Carpenter JF: Effect of Tween 20 on freeze-thawing- and agitation-induced aggregation of recombinant human factor XIII. J Pharm Sci 87: 1597-1603, 1998.

36. Pikal-Cleland KA and Carpenter JF: Lyophilization-induced protein denaturation in phosphate buffer systems: Monomeric and tetrameric beta-galactosidase. J Pharm Sci 90: 1255-1268, 2001.

37. Klibanov AM: Enzymatic catalysis in anhydrous organic solvents. Trends Biochem Sci 14: 141-144, 1989.

38. Mandal BB and Kundu SC: Calcium alginate beads embedded in silk fibroin as 3D dual drug releasing scaffolds. Biomaterials 30: 5170-5177, 2009.

39. Nwe N, Furuike T and Tamura H: The mechanical and biological properties of chitosan scaffolds for tissue regeneration templates are significantly enhanced by chitosan from gongronella butleri. Materials 2: 374-398, 2009.

40. Neamnark A, Sanchavanakit N, Pavasant P, Bunaprasert T, Supaphol P and Rujiravanit R: In vitro biocompatibility evaluations of hexanoyl chitosan film. Carbohydrate Polymers 68: 166-172, 2007.

41. Bonewald LF and Mundy GR: Role of transforming growth factor beta in bone remodeling: A review. Connect Tissue Res 23: 201-208, 1989. 